\title{
Performance of Aluminium Hydroxide Gel and ISA Oils Adjuvanted Foot and Mouth Disease Vaccines
}

\author{
Wael M. Gamaledin, Ehab Elsayed, Amr I. Hassanin, Assem A. Mohamed*, Walaa Shabana \\ Department of FMD, Veterinary Serum and Vaccine Research Institute (VSVRI), Abassia, Cairo, Egypt \\ *Corresponding Author: Assem A. Mohamed, Department of FMD, Veterinary Serum and Vaccine \\ Research Institute (VSVRI), Abassia, Cairo, Egypt. Email: svri@idsc.gov.eg
}

\begin{abstract}
Background: Adjuvant plays an important role in the efficacy of vaccines, the protective immune responses produced by vaccine could vary according to the kinds of adjuvants.
\end{abstract}

Objective: Comprehensive sero-immunological study was conducted to reveal the adjuvant's effect of on the immune response of polyvalent Foot and mouth disease (FMD) vaccine in cattle.

Methods: This study was conducted on twenty-seven cattle in Kaliobia governorate, Egypt. Twenty animals was divided into four groups, each of five animals, one group vaccinated intramuscularly (I/M) with trivalent FMD ISA 206 oil vaccine, second group vaccinated intramuscularly (I/M) with trivalent FMD ISA 206aluminum hydroxide gel vaccine, third group vaccinated intramuscularly (I/M) with trivalent ISA 201 oil vaccine, fourth group vaccinated intramuscularly (I/M) with trivalent ISA 201-aluminum hydroxide gel vaccine, three cattle were used as negative control (non-vaccinated) and four cattle were used for safety test. Serum samples were collected from vaccinated animals for 10 months. The cellular and humeral immune responses were monitored.

Results: Our results showed that the groups immunized with the vaccines prepared with ISA 201 and ISA 201 +aluminum hydroxide gel induced better cellular immunity than that induced by vaccines prepared with ISA 206 and ISA 206 + aluminum hydroxide gel, also found that vaccines prepared with ISA 206 and ISA 206 +aluminum hydroxide gel induce better humeral immunity than that induced by vaccines prepared with ISA 201 and ISA 201 + aluminum hydroxide gel. Immune response with ISA oils and aluminium hydroxide gel overcomes that with ISA oils alone.

Conclusion: Finally we concluded that aluminum hydroxide gel improves the effects of ISA adjuvants.

Keywords: FMD vaccines, ISA, aluminum hydroxide gel.

\section{INTRODUCTION}

Foot-and-mouth disease (FMD) is an acute infectious disease that infects cloven-hoofed mammals, such as pigs, cattle, cattle and goats Dara, et al., (2013). The causative agent is a single stranded positive- sense RNA virus that belongs to the genus Aphthovirus in the family Picornaviridae. The virus has seven serological types, identified as; O, A, C, SAT1, SAT2, SAT3 and Asia1 Dara, et al., (2013).

FMD is characterized by fever, lameness and vesicular lesions on the feet, tongue, snout, and teats, with high morbidity and low mortality

\section{Rodriguez and Grubman (2009).}

In Egypt, the disease is enzootic and outbreaks have been reported since 1950 and Mousa et al.,

ARC Journal of Animal and Veterinary Sciences
1974). Type O was the most prevalent since 1960 Zahran (1960), Farag et al., (2005) and Satya (2009). FMDV serotype A was isolated during 2006 in Egypt through live animals importation where sever clinical signs were recorded among cattle and buffaloes Abed ElRahman (2006)., Also FMDV serotype SAT2 was recorded in Egypt Shawkey et al., (2013) and Nader et al., (2014).

Control of FMD in animals was considered to be important to effectively contain the disease in endemic areas, so that vaccination of animals is effective in limiting the spread of FMD Longjam et al., (2011) and Depa et al., (2012).

Adjuvants, also can prolong the immune response and stimulate specific components of the immune response either humeral or cell 
mediated immunity (Barnett (2003) and Lombard et al. (2007). An ideal adjuvant is one which can stimulate the humeral immune response early (onset), and promote production of high antibody titers that would long duration. It should also stimulate the cellular immune response Park (2013).

The oil adjuvant has the capability for generating a rapid, high and long-lasting immune response. Generally, the Montanide series of oil adjuvants (SEPPIC, France) has a clear immunological effect for inactivated vaccine in different susceptible animals Dara, et al., (2013), Ehab et al., (2015) and Fakhry et al., (2012).

Vaccines containing aluminum hydroxide and saponin as adjuvants have several deficiencies such as the induction of short-lived antibody responses which require relatively frequent revaccinations at intervals of 6 or even 4 months. In contrast, oil-based adjuvant FMD vaccines appear to have several advantages such as the induction of high titers and long-lived antibody responses, resulting in more effective protection Aucouturier et al., (2001), Cloete al., (2008). Unlike alum-based adjuvant vaccines, oil-based adjuvant vaccines can overcome interference by maternal antibodies in neonates and can consequently be applied earlier in life Iyer et al., (2000) and (2003).

The objective of this study was to reveal the adjuvant's effect of different adjuvants on the immune response of trivalent Foot and mouth disease (FMD) vaccine in cattle.

\section{Materials ANd MethodS}

\subsection{Animals (Cattle)}

Twenty seven calves, native breed, between 6 to 9 months old and weighted between 300 and $400 \mathrm{~kg}$, twenty calves were divided into four groups, each of five animals, one group vaccinated intramuscularly $(\mathrm{I} / \mathrm{M})$ with trivalent FMD ISA 206 oil vaccine, second group vaccinated intramuscularly $(\mathrm{I} / \mathrm{M})$ with trivalent FMD ISA 206- aluminum hydroxide gel vaccine, third group vaccinated intramuscularly (I/M) with trivalent ISA 201 oil vaccine,, fourth group vaccinated intramuscularly $(\mathrm{I} / \mathrm{M})$ with trivalent ISA 201- aluminum hydroxide gel vaccine, three cattle were used as negative control (non-vaccinated) and four cattle were used for safety test.

ARC Journal of Animal and Veterinary Sciences

\subsection{FMD virus Strains}

FMD virus local strains (O /pan Asia2, A/ Iran 05, SAT2/ Egypt 2012 and SAT2/ Egypt 2018) were locally isolated and were identified by Veterinary Serum and Vaccine Research Institute, Abbasia, Cairo. These viruses were used in vaccine preparation and serum neutralization test (SNT).

\subsection{Adjuvants}

A-ISA206: Montanide ISA 206 was obtained from Seppic, Paris, France.

B-ISA201: Montanide ISA 201 was obtained from Seppic, Paris, France.

C-Aluminium Hydroxide Gel: $2.5 \%$ aluminum hydroxide gel was prepared as an alum-based adjuvant.

\subsection{FMD Polyvalent Vaccine}

Local strains of FMD were propagated in baby hamster kidney cells- clone 21 (BHK-21) cell line and inactivated by Binary Ethylenemine (BEI).

\section{A. Preparation of the ISA 206 Adjuvant Vaccine}

Inactivated ISA 206 oil adjuvanated FMD Vaccines were formulated according to Barnett.et.al. (1996). The ratio of the aqueous antigen to the oil adjuvant was 50:50 (w/w) according to OIE (2000).

\section{B. Preparation of the ISA206 - Aluminium Hydroxide Gel Adjuvant Vaccine}

Inactivated ISA 206 oil adjuvanated FMD Vaccines were formulated according to Barnett.et.al. (1996). The ratio of the aqueous antigen to the oil adjuvant was 50:50 (w/w) according to OIE (2000). Aluminium hydroxide gel was added as $30 \%$ of the aqueous phase of the vaccine bulk.

\section{Preparation of the ISA201 Adjuvant Vaccines}

Inactivated ISA 201 oil adjuvanated FMD Vaccines were formulated according to Barnett.et.al. (1996). The ratio of the aqueous antigen to the oil adjuvant was 50:50 (w/w) according to OIE (2000).

\section{Preparation of the ISA206 - Aluminium Hydroxide Gel Adjuvant Vaccines}

Inactivated ISA 201 oil adjuvanated FMD Vaccines were formulated according to Barnett.et.al. (1996). The ratio of the aqueous antigen to the oil adjuvant was 50:50 (w/w) according to OIE (2000). Aluminium hydroxide 
gel was added as $30 \%$ of the aqueous phase of the vaccine bulk.

Immune response of vaccinated cattle were determine by using Lymphocyte blastogenesis using XTT assay according to Scudiero et al. (1988) and SNT test against FMDV strains (O /pan Asia2, A/ Iran 05, SAT2/ Egypt 2012 and SAT2/ Egypt 2018) in serum samples according to (Voller et al., 1976 and OIE 2012).

\subsection{Safety of the Prepared Vaccines}

Safety test for the formulated FMD vaccines: The inactivated FMD virus was tested for safety in vitro on BHK-21 cell line and the whole prepared vaccines in vivo in susceptible cattle OIE (2000).

Safety of the prepared vaccines were done according to Code of Federal regulation of USA. (1986), Henderson (1970) and OIE (2000).

\section{EXPERIMENTAL DESIGN}

Twenty seven calves, native breed, between 6 to 9 months old and weighted between 300 and $400 \mathrm{~kg}$, twenty calves were divided into four groups, each of five animals, one group vaccinated intramuscularly $(\mathrm{I} / \mathrm{M})$ with trivalent FMD ISA 206 oil vaccine, second group vaccinated intramuscularly $(\mathrm{I} / \mathrm{M})$ with trivalent FMD ISA 206- aluminum hydroxide gel vaccine, third group vaccinated intramuscularly (I/M) with trivalent ISA 201 oil vaccine,, fourth group vaccinated intramuscularly (I/M) with trivalent ISA 201- aluminum hydroxide gel vaccine, three cattle were used as negative control (non-vaccinated) and four cattle were used for safety test. Serum samples were collected from vaccinated animals for 10 months.

Table1. Safety of polyvalent FMD vaccines tested

\begin{tabular}{|c|c|c|c|c|}
\hline \multirow{2}{*}{$\begin{array}{c}\text { Months } \\
\text { post vaccination }\end{array}$} & \multicolumn{4}{|c|}{ Polyvalent FMD Vaccines } \\
\cline { 2 - 5 } & ISA201 & ISA201+AL* & ISA206 & ISA206+AL* \\
\hline 1 & safe & safe & safe & safe \\
\hline 2 & safe & safe & safe & safe \\
\hline 3 & safe & safe & safe & safe \\
\hline 4 & safe & safe & safe & safe \\
\hline 5 & safe & safe & safe & safe \\
\hline 6 & safe & safe & safe & safe \\
\hline 7 & safe & safe & safe & safe \\
\hline 8 & safe & safe & safe & safe \\
\hline 9 & safe & safe & & \\
\hline
\end{tabular}

AL * aluminium hydroxide gel

Heparinized blood samples were obtained from vaccinated and control non vaccinated animals at $0,3,7,14,21,28,35$ and 42 days post vaccination. Stimulation of the cellular immune response by the different prepared FMD vaccine was evaluated by Lymphocyte blastogenesis using cell proliferation kit (XTT kit).

Serum samples were collected weekly post vaccination for one month then every month post-vaccination till the end of experiment (ten months). The immune response was evaluated through SNT test.

\section{RESULTS AND DISCUSSION}

Foot and Mouth Disease (FMD) is an acute disease caused by Foot and Mouth Disease Virus (FMDV) which causes important economy losses (Orsel et al., 2007). The control of FMD in animals was considered to be important to effectively contain the disease in endemic areas, so that vaccination of animals is effective in limiting the spread of FMD.

FMD vaccines can be defined as a fixed formulation of that of specific amount of chemically inactivated virus strains and mixing with suitable adjuvant. Selecting the suitable vaccine formulation is dependent on several factors as the onset of protection and the duration of protection against FMD.

The effective formulation of inactivated FMD vaccines requires adjuvant aluminium hydroxide gel and mineral oils-based formulations have been widely employed in experimental studies to obtain a vaccine that stimulates a rapid and long-lasting protective immune response, the formulated vaccines are safe for animal use.

Results in table (1) showed that the five prepared vaccines were safe for use during the whole experiment time. These results were in agreement with (OIE 2000). 
The obtained results of cell mediated immune response using lymphocyte proliferation test for all animal groups expressed by $\triangle \mathrm{OD}$ (Delta Optical Density) were as follow:

Group 1 (polyvalent FMD ISA 206 oil vaccine): Delta Optical Density was $(0.583)$ by using FMD viruses at $3^{\text {rd }}$ day post vaccination and still rise reached its highest level (1.557) at 3rd week post vaccination and continue high within examination time 35 days post vaccination.

Group 2 (polyvalent FMD ISA 206- aluminum hydroxide gel vaccine): Delta Optical Density was $(0.536)$ by using FMD viruses at $3^{\text {rd }}$ day post vaccination and still rise reached its highest level (1.166) at $3^{\text {rd }}$ week post vaccination then declined gradually.

Group 3 (polyvalent ISA 201 oil vaccine): Delta Optical Density was (0.588) by using FMD viruses at $3^{\text {rd }}$ day post vaccination and still rise reached its highest level (1.6628) at $3^{\text {rd }}$ week post vaccination and continue high within examination time 35 days post vaccination.

Group 4 (polyvalent ISA 201- aluminum hydroxide gel vaccine): Delta Optical Density was $(0.5956)$ by using FMD viruses at $3^{\text {rd }}$ day post vaccination and still rise reached its highest level $(1.7628)$ at $3^{\text {rd }}$ week post vaccination then declined gradually as shown in tables (2, 3, 4 and 5).

Table2. Delta optical density of the cell-mediated immune response of cattle vaccinated with polyvalent FMD ISA 206 oil vaccine using lymphocyte Proliferation (XTT) Assay

\begin{tabular}{|c|c|c|c|c|c|c|c|}
\hline \multirow{2}{*}{$\begin{array}{c}\text { Time } \\
\text { post vaccination }\end{array}$} & \multicolumn{5}{|c|}{$\Delta O D$ in buffy coat in Vaccinated cattle } & \multirow[t]{2}{*}{ Mean } & \multirow{2}{*}{$\begin{array}{c}\text { Control } \\
\text { non vaccinated animal }\end{array}$} \\
\hline & $1 *$ & 2 & 3 & 4 & 5 & & \\
\hline Pre vaccination & 0.051 & 0.050 & 0.049 & 0.048 & 0.046 & 0.0488 & 0.064 \\
\hline $3^{\text {rd }}$ day & 0.590 & 0.578 & 0.578 & 0.592 & 0.572 & 0.583 & 0.065 \\
\hline 1 week & 0.851 & 0.854 & 0.852 & 0.850 & $\mathbf{0 . 8 4 7}$ & 0.8508 & 0.056 \\
\hline 2 week & 1.498 & 1.492 & 1.496 & 1.456 & 1.398 & 1.468 & 0.069 \\
\hline 3 week & 1.558 & 1.562 & 1.560 & 1.544 & 1.562 & $\mathbf{1 . 5 5 7 2}$ & 0.067 \\
\hline 4 week & 1.258 & 1.262 & 1.260 & 1.255 & 1.250 & 1.257 & 0.065 \\
\hline 5 week & 0.830 & 0.832 & 0.830 & 0.845 & 0.798 & 1.257 & 0.064 \\
\hline 6 week & 0.640 & 0.644 & 0.641 & 0.651 & 0.611 & 0.827 & 0.065 \\
\hline
\end{tabular}

Table3. Delta optical density of the cell-mediated immune response of cattle, vaccinated with polyvalent FMD ISA 206- aluminum hydroxide gel vaccine using lymphocyte Proliferation (XTT) Assay

\begin{tabular}{|c|c|c|c|c|c|c|c|}
\hline \multirow{2}{*}{ Time post vaccination } & \multicolumn{4}{|c|}{$\Delta$ OD in buffy coat in Vaccinated cattle } & \multirow{2}{*}{ Mean } & \multirow{2}{*}{$\begin{array}{c}\text { Control non vaccinated } \\
\text { animal }\end{array}$} \\
\cline { 2 - 6 } & $1^{*}$ & 2 & 3 & 4 & 5 & & $\mathbf{0 . 0 6 4}$ \\
\hline Pre vaccination & $\mathbf{0 . 0 4 8}$ & $\mathbf{0 . 0 5 0}$ & $\mathbf{0 . 0 4 8}$ & $\mathbf{0 . 0 4 1}$ & $\mathbf{0 . 0 4 6}$ & $\mathbf{0 . 0 4 6 6}$ & $\mathbf{0 . 0 6 5}$ \\
\hline $3^{\text {rd }}$ day & $\mathbf{0 . 5 5 0}$ & $\mathbf{0 . 5 4 8}$ & $\mathbf{0 . 5 2 8}$ & $\mathbf{0 . 5 3 2}$ & $\mathbf{0 . 5 2 2}$ & $\mathbf{0 . 5 3 6}$ & $\mathbf{0 . 0 5 6}$ \\
\hline 1 week & $\mathbf{0 . 9 5 1}$ & $\mathbf{0 . 8 5 4}$ & $\mathbf{0 . 8 5 2}$ & $\mathbf{0 . 8 4 0}$ & $\mathbf{0 . 8 3 2}$ & $\mathbf{0 . 8 6 6}$ & $\mathbf{0 . 0 6 9}$ \\
\hline 2 week & $\mathbf{1 . 6 9 8}$ & $\mathbf{1 . 6 9 2}$ & $\mathbf{1 . 6 9 6}$ & $\mathbf{1 . 5 8 0}$ & $\mathbf{1 . 6 1 1}$ & $\mathbf{1 . 6 5 5}$ & $\mathbf{0 . 0 6 7}$ \\
\hline 3 week & $\mathbf{1 . 6 5 8}$ & $\mathbf{1 . 6 6 2}$ & $\mathbf{1 . 6 6 0}$ & $\mathbf{1 . 6 1}$ & $\mathbf{1 . 7 1 2}$ & $\mathbf{1 . 6 6 0}$ & $\mathbf{0 . 0 6 5}$ \\
\hline 4 week & $\mathbf{1 . 4 5 8}$ & $\mathbf{1 . 4 6 2}$ & $\mathbf{1 . 4 6 0}$ & $\mathbf{1 . 4 2 3}$ & $\mathbf{1 . 4 9 1}$ & $\mathbf{1 . 4 5 9}$ & $\mathbf{0 . 0 6 4}$ \\
\hline 5 week & $\mathbf{0 . 9 4 0}$ & $\mathbf{0 . 9 4 4}$ & $\mathbf{0 . 9 4 1}$ & $\mathbf{0 . 9 2 4}$ & $\mathbf{0 . 9 1 9}$ & $\mathbf{0 . 9 3 4}$ & $\mathbf{0 . 0 6 5}$ \\
\hline 6 week & $\mathbf{0 . 8 2 7}$ & $\mathbf{0 . 8 2 8}$ & $\mathbf{0 . 8 2 7}$ & $\mathbf{0 . 8 6 2}$ & $\mathbf{0 . 8 9 6}$ & $\mathbf{0 . 8 4 8}$ & \\
\hline
\end{tabular}

Table4. Delta optical density of the cell-mediated immune response of cattle, vaccinated with polyvalent ISA 201 oil vaccine using lymphocyte Proliferation (XTT) Assay

\begin{tabular}{|c|c|c|c|c|c|c|c|}
\hline \multirow[t]{2}{*}{ Time post vaccination } & \multicolumn{5}{|c|}{$\Delta O D$ in buffy coat in Vaccinated cattle } & \multirow[t]{2}{*}{ Mean } & \multirow{2}{*}{$\begin{array}{c}\text { Control } \\
\text { non vaccinated animal }\end{array}$} \\
\hline & $1 *$ & 2 & 3 & 4 & 5 & & \\
\hline Pre vaccination & 0.048 & 0.050 & 0.048 & 0.036 & 0.041 & 0.044 & 0.064 \\
\hline $3^{\text {rd }}$ day & 0.590 & 0.578 & 0.593 & 0.592 & 0.588 & 0.588 & 0.065 \\
\hline 1 week & 0.587 & 0.572 & 0.578 & 0.581 & 0.578 & 0.490 & 0.056 \\
\hline 2 week & 1.113 & 1.117 & 1.114 & 1.242 & 1.211 & 1.136 & 0.069 \\
\hline 3 week & 1.658 & 1.662 & 1.660 & 1.622 & 1.712 & 1.6628 & 0.067 \\
\hline 4 week & 0.782 & 0.780 & 0.782 & 0.783 & 0.758 & 0.777 & 0.065 \\
\hline 5 week & 0.683 & 0.683 & 0.684 & 0.662 & 0.668 & 0.676 & 0.064 \\
\hline 6 week & 0.636 & 0.641 & 0.638 & 0.611 & 0.609 & 0.627 & 0.065 \\
\hline
\end{tabular}


Table5. Delta optical density of the cell-mediated immune response of cattle, vaccinated with polyvalent ISA 201- aluminum hydroxide gel vaccine using lymphocyte roliferation (XTT) Assay

\begin{tabular}{|c|c|c|c|c|c|c|c|}
\hline \multirow{2}{*}{$\begin{array}{c}\text { Time } \\
\text { post vaccination }\end{array}$} & \multicolumn{5}{|c|}{$\Delta O D$ in buffy coat in Vaccinated cattle } & \multirow[t]{2}{*}{ Mean } & \multirow{2}{*}{$\begin{array}{c}\text { Control } \\
\text { non vaccinated animal }\end{array}$} \\
\hline & $1 *$ & 2 & 3 & 4 & 5 & & \\
\hline Pre vaccination & 0.048 & 0.050 & 0.048 & 0.041 & 0.046 & 0.0466 & 0.064 \\
\hline $3^{\text {rd }}$ day & 0.597 & 0.598 & 0.593 & 0.592 & 0.598 & 0.5956 & 0.065 \\
\hline 1 week & 0.951 & 0.854 & 0.852 & 0.840 & $\mathbf{0 . 8 3 2}$ & 0.8658 & 0.056 \\
\hline 2 week & 1.698 & 1.692 & 1.696 & 1.580 & 1.611 & 1.655 & 0.069 \\
\hline 3 week & 1.758 & 1.862 & 1.760 & 1.672 & 1.762 & 1.7628 & 0.067 \\
\hline 4 week & 1.458 & 1.462 & 1.460 & 1.423 & 1.491 & 1.459 & 0.065 \\
\hline 5 week & 0.940 & 0.944 & 0.941 & 0.924 & 0.919 & 0.934 & 0.064 \\
\hline 6 week & 0.827 & 0.828 & 0.827 & 0.862 & 0.896 & 0.848 & 0.065 \\
\hline
\end{tabular}

Tables 2,3,4 and 5 showed that vaccines of the antibodies elicited by the different prepared with ISA 201 and ISA $201+$ aluminum hydroxide gel induced better cellular immunity than that induced by vaccines prepared with ISA 206 and ISA 2016+aluminum hydroxide gel, these results appeared to be supported by (Knudsen et al., (1979), Sharma et al., (1984) who reported that cell mediated immune response was a constitute of immune response against FMD virus, and in agreement in some points with (Knudsen et al., (1979), Mercedes et al.,(1996) ,Elwatany et al.,(1999), Sonia et al., (2010) , ,Hiam et al., 2012 and El-Din, W et al.,(2014) who found that FMD vaccine stimulated the cellular immune response and lymphocyte stimulation by FMDV was greater than by mitogens (PHA) and appeared the highest increase in $1^{\text {st }}$ and $2^{\text {nd }}$ weeks post vaccination.

The SNT data in tables 6,7,8 and 9 showed the differences in the onset, intensity and duration vaccine formulations against FMD virus serotypes O, A, SAT2/2012 and SAT2/2018. Results showed that vaccines prepared with ISA 206 and ISA 206+aluminum hydroxide gel induce better humeral immunity than that induced by vaccines prepared with ISA 201 and ISA $201+$ aluminum hydroxide gel, the results obtained are consistent with the statement of Wisniewski et al., (1972) they explained that the SNT measures those antibodies which neutralize the infectivity of FMD virion. The peak of antibody titre in all groups at 10-12 weeks post vaccination and continues with protective level till $32^{\text {th }}$ week post vaccination. Our results also were consistent with the statement of (Hamblin et al., (1986) who explained that the SNT measures those antibodies which neutralize the infectivity of FMD virion, while ELISA probably measure all classes of antibodies even those produced against incomplete and non-infectious virus.

Table6. Mean of serum antibody titers in cattle vaccinated with polyvalent FMD ISA 206 oil vaccine using SNT expressed $\log _{10}$

\begin{tabular}{|c|c|c|c|c|c|}
\hline \multirow{2}{*}{$\begin{array}{l}\text { Weeks post } \\
\text { vaccination }\end{array}$} & \multicolumn{4}{|c|}{ Mean antibody titer against FMD virus strains } & \multirow{2}{*}{$\begin{array}{c}\text { Non vaccinated } \\
\text { Group }\end{array}$} \\
\hline & FMD (O) & FMD (A) & FMD (SAT/2012) & FMD (SAT/2018) & \\
\hline Pre-vaccination & 0.27 & 0.27 & 0.15 & 0.3 & 0.3 \\
\hline 1 & 1.1 & 1.05 & 1.2 & 1.2 & 0.3 \\
\hline 2 & 1.65 & 1.8 & 1.8 & 1.8 & 0.3 \\
\hline 3 & 2.1 & 2.1 & 1.95 & 1.95 & 0.3 \\
\hline 4 & 2.4 & 2.4 & 2.4 & 2.1 & 0.3 \\
\hline 6 & 2.7 & 2.7 & 2.7 & 2.7 & 0.3 \\
\hline 8 & 2.85 & 2.85 & 2.85 & 2.85 & 0.3 \\
\hline 10 & 2.85 & 3.15 & 3.15 & 3.0 & 0.3 \\
\hline 12 & 2.55 & 2.85 & 3.0 & 2.85 & 0.3 \\
\hline 14 & 2.55 & 2.7 & 2.85 & 2.85 & 0.3 \\
\hline 16 & 2.4 & 2.4 & 2.7 & 2.55 & 0.3 \\
\hline 20 & 2.1 & 2.1 & 2.4 & 2.4 & 0.3 \\
\hline 24 & 1.8 & 1.8 & 2.1 & 2.1 & 0.3 \\
\hline 28 & 1.65 & 1.65 & 1.8 & 1.65 & 0.3 \\
\hline 32 & 1.5 & 1.5 & 1.65 & 1.65 & 0.3 \\
\hline 36 & 1.05 & 1.05 & 1.2 & 1.2 & 0.3 \\
\hline 40 & 0.75 & 0.6 & 0.75 & 0.6 & 0.3 \\
\hline
\end{tabular}


Table7. Mean of serum antibody titers in cattle vaccinated with polyvalent FMD ISA 206-aluminum hydroxide gel vaccine using SNT expressed $\log _{10}$

\begin{tabular}{|c|c|c|c|c|c|}
\hline \multirow{2}{*}{$\begin{array}{c}\text { Weeks } \\
\text { post vaccination }\end{array}$} & \multicolumn{4}{|c|}{ Mean antibody titer against FMD virus strains } & \multirow{2}{*}{$\begin{array}{l}\text { Non vaccinated } \\
\text { Group }\end{array}$} \\
\hline & FMD (O) & FMD (A) & FMD (SAT/2012) & FMD (SAT/2018) & \\
\hline Pre-vaccination & 0.27 & 0.27 & 0.15 & 0.3 & 0.3 \\
\hline 1 & 1.1 & 1.05 & 1.2 & 1.2 & 0.3 \\
\hline 2 & 1.65 & 1.8 & 1.8 & 1.8 & 0.3 \\
\hline 3 & 2.1 & 2.1 & 1.95 & 1.8 & 0.3 \\
\hline 4 & 2.4 & 2.4 & 2.4 & 2.1 & 0.3 \\
\hline 6 & 2.7 & 2.7 & 2.7 & 2.7 & 0.3 \\
\hline 8 & 2.85 & 2.85 & 2.85 & 2.85 & 0.3 \\
\hline 10 & 3.15 & 3.15 & 3.1 & 3.0 & 0.3 \\
\hline 12 & 315 & 3.0 & 3.0 & 3.0 & 0.3 \\
\hline 14 & 2.55 & 2.7 & 2.85 & 2.7 & 0.3 \\
\hline 16 & 2.4 & 2.4 & 2.7 & 2.55 & 0.3 \\
\hline 20 & 2.1 & 2.1 & 2.4 & 2.1 & 0.3 \\
\hline 24 & 1.8 & 1.8 & 2.1 & 2.1 & 0.3 \\
\hline 28 & 1.65 & 1.65 & 1.8 & 1.65 & 0.3 \\
\hline 32 & 1.5 & 1.5 & 1.65 & 1.5 & 0.3 \\
\hline 36 & 1.05 & 1.05 & 1.2 & 1.2 & 0.3 \\
\hline 40 & 0.75 & 0.6 & 0.75 & 0.6 & 0.3 \\
\hline
\end{tabular}

Table8. Mean of serum antibody titers in cattle vaccinated with polyvalent ISA 201 oil vaccine using SNT expressed $\log _{10}$

\begin{tabular}{|c|c|c|c|c|c|}
\hline \multirow{2}{*}{$\begin{array}{c}\text { Weeks } \\
\text { post vaccination }\end{array}$} & \multicolumn{4}{|c|}{ Mean antibody titer against FMD virus strains } & \multirow{2}{*}{$\begin{array}{c}\text { Non vaccinated } \\
\text { Group }\end{array}$} \\
\hline & FMD (O) & FMD (A) & FMD (SAT/2012) & FMD (SAT/2018) & \\
\hline Pre-vaccination & 0.27 & 0.27 & 0.15 & 0.3 & 0.3 \\
\hline 1 & 1.1 & 1.05 & 1.2 & 1.2 & 0.3 \\
\hline 2 & 1.65 & 1.8 & 1.8 & 1.8 & 0.3 \\
\hline 3 & 2.1 & 2.1 & 1.95 & 1.95 & 0.3 \\
\hline 4 & 2.4 & 2.4 & 2.4 & 2.1 & 0.3 \\
\hline 6 & 2.7 & 2.7 & 2.7 & 2.7 & 0.3 \\
\hline 8 & 2.85 & 2.85 & 2.85 & 2.85 & 0.3 \\
\hline 10 & 2.85 & 3.0 & 2.85 & 2.85 & 0.3 \\
\hline 12 & 2.55 & 2.85 & 2.85 & 2.85 & 0.3 \\
\hline 14 & 2.55 & 2.7 & 2.7 & 2.7 & 0.3 \\
\hline 16 & 2.4 & 2.4 & 2.7 & 2.55 & 0.3 \\
\hline 20 & 2.1 & 2.1 & 2.4 & 2.1 & 0.3 \\
\hline 24 & 1.8 & 1.8 & 2.1 & 2.1 & 0.3 \\
\hline 28 & 1.65 & 1.65 & 1.8 & 1.65 & 0.3 \\
\hline 32 & 1.5 & 1.5 & 1.65 & 1.5 & 0.3 \\
\hline 36 & 1.05 & 1.05 & 1.2 & 1.2 & 0.3 \\
\hline 40 & 0.75 & 0.6 & 0.75 & 0.6 & 0.3 \\
\hline
\end{tabular}

Table9. Mean of serum antibody titers in cattle vaccinated with polyvalent ISA 201-aluminum hydroxide gel vaccine using SNT expressed $\log _{10}$

\begin{tabular}{|c|c|c|c|c|c|}
\hline \multirow{2}{*}{$\begin{array}{c}\text { Weeks post } \\
\text { vaccination }\end{array}$} & \multicolumn{3}{|c|}{ Mean antibody titer against FMD virus strains } & $\begin{array}{c}\text { Non } \\
\text { vaccinated } \\
\text { Group }\end{array}$ \\
\cline { 2 - 5 } Pre-vaccination & $\mathbf{F M D}(\mathbf{O})$ & FMD (A) & FMD (SAT/2012) & FMD (SAT/2018) & 0.3 \\
\hline 1 & 1.1 & 0.27 & 0.15 & 0.3 & 0.3 \\
\hline 2 & 1.65 & 1.0 & 1.2 & 1.2 & 0.3 \\
\hline 3 & 2.1 & 2.1 & 1.95 & 1.8 & 0.3 \\
\hline 4 & 2.4 & 2.4 & 2.4 & 2.1 & 0.3 \\
\hline 6 & 2.7 & 2.7 & 2.7 & 2.7 & 0.3 \\
\hline 8 & 2.85 & 2.85 & 2.85 & 2.85 & 0.3 \\
\hline 10 & 2.85 & 3.15 & 3.1 & 3.0 & 0.3 \\
\hline 12 & 2.55 & 2.85 & 3.0 & 2.85 & 0.3 \\
\hline 14 & 2.55 & 2.7 & 2.85 & 2.85 & 0.3 \\
\hline
\end{tabular}




\begin{tabular}{|l|c|c|c|c|c|}
\hline 16 & 2.4 & 2.4 & 2.7 & 2.55 & 0.3 \\
\hline 20 & 2.1 & 2.1 & 2.4 & 2.1 & 0.3 \\
\hline 24 & 1.8 & 1.8 & 2.1 & 2.1 & 0.3 \\
\hline 28 & 1.65 & 1.65 & 1.8 & 1.65 & 0.3 \\
\hline 32 & 1.5 & 1.5 & 1.65 & 1.5 & 0.3 \\
\hline 36 & 1.05 & 1.05 & 1.2 & 1.05 & 0.3 \\
\hline 40 & 0.75 & 0.6 & 0.75 & 0.6 & 0.3 \\
\hline
\end{tabular}

The selection of adjuvants in FMD vaccine formulation is important for both early and long-lasting immunity and protection Park et al., (2014). The aluminium hydroxide gel is the most commonly used adjuvant in commercial vaccines Rimaniol and Gras (2004). A previous report showed that aluminium hydroxide gel induces Th2-type responses in animal models, facilitating the dissemination of antibodies from the injected region Gupta etal., (1995) and Brewer et al.,(1996). In addition, the aluminium hydroxide gel was shown to play an important role in memory responses by inducing the differentiation of macro- phages. Geladjuvanated FMD vaccines are currently used only in cattle, because they offer only a short period of immunity, making them unsuitable for use in pigs Park (2013). Moreover, the immune responses in sheep and goats are poorer than those of oil-based vaccines Patil et al., $(2002$ a,b). The combined components of oil and aluminium hydroxide gel have been used to protect against rabies in bovines Reddy and Srinivasan (1996).

In this study, we tested a combination of oil with aluminium hydroxide gel to enhance the immune responses. We found that vaccines prepared with ISA 201 and ISA $201+$ aluminum hydroxide gel induced better cellular immunity than that induced by vaccines prepared with ISA 206 and ISA 2016+aluminum hydroxide gel, also found that vaccines prepared with ISA 206 and ISA $206+$ aluminum hydroxide gel induce better humeral immunity than that induced by vaccines prepared with ISA 201 and ISA $201+$ aluminum hydroxide gel. We concluded that aluminum hydroxide gel improves the effects of ISA adjuvants.

In the present study, we thus attempted to demonstrate that mixing of various oiladjuvants and aluminium hydroxide gel would induces similar protection in cattle. We confirmed slight increases in the level of cellular and humeral immune response after using aluminium hydroxide gel.

Finally, Oil-adjuvanated vaccines can result in the formation of local lesions in the injected areas. Thus, to avoid granuloma, long-term studies with a reduced volume of vaccines should be carried out to identify whether such lesions increase or decrease when aluminum hydroxide gel is added to the vaccines. In addition, comparative studies on long-lasting immunity in experimental and target animals may be required for the development of new vaccines.

\section{REFERENCES}

[1] Abdel- Rahman, A. O., Farag, M. A., Samira El- Kilany, Eman, M. A., Manal Abo El Yazed and Zeidan, S.: Isolation and identification of FMDV during an outbreak of 2006 in Egypt. Kafr El- Sheikh Vet. Med. J.; 4(1): (2006).

[2] Aucouturier, J., Dupuis, L. and Ganne, V.: Adjuvants designed for veterinary and human vaccines. Vaccine. (2001);19:2666-2672.

[3] Barnett, P., Pullen, L. Williams, L. and Doel, T.R: Assessment of Montanide ISA 25 and ISA 206, two commercially available oil adjuvant. Vaccine, (1996) 14(13):1187-1198.

[4] Barnett,P.V.; Statham, R.J.; Vosloo, W. and Haydon, D.T.: "Foot-and-mouth disease vaccine potency testing: determination and statistical validation of a model using a serological approach." Vaccine (2003) 4, 21(23):3240-8.

[5] Brewer,J.M., Conacher,M., Satoskar,A., Bluethmann,H. and Alexander,J.: In interleukin-4-deficient mice, alum not only generates $\mathrm{T}$ helper 1 responses equivalent to Freund's complete adjuvant, but continues to induce T helper 2 cytokine production, Eur. J. Immunol. 26 (1996) 2062-2066.

[6] Cloete,M., Dungu, B., Van Staden, L., IsmailCassim, N., Vosloo, W.: Evaluation of different adjuvants or foot-and-mouth disease vaccine containing all the SAT serotypes. Onderstepoort J Vet Res. (2008); 75:17-31.

[7] Code of Federal regulation of USA: Published by the office of the federal register national archives and Record administration, Animal and animal products 9 / (1986).

[8] Dara P., Kalaivanana R., Sied N., Mamo B., Kishore S., Suryanaraya V.V., Kondabattula G.: Montanide ISA201 adjuvanted FMD vaccine induces improved immune responses and protection in cattle. Vaccine J. 2013; 31:3327-3332. 
[9] Depa, P.M., Dimri, U., Sharma, M.C. and Tiwari, R: Update on epidemiology and control of foot and mouth disease - A menace to international trade and global animal enterprise. Vet. World, (2012) 5(11): 694-704.

[10] Ehab El-Sayed Ibrahim, Wael Mossad Gamal, Amr Ismail Hassan, Safy ElDinMahdy, Akram Zakria Hegazy and Magdy Mahmoud Abdel-Atty: Comparative study on the immunopotentiator effect of ISA 201, ISA 61, ISA 50, ISA206 used in trivalent foot and mouth disease vaccine. Veterinary World (2015), EISSN:22310916, P.(11891198) .

[11] El-Din,W.M., Ibrahim, E.E., Daoud, H. and Ali, S.M.: Humeral and cellular immune response of Egyptian trivalent foot and mouth disease oil vaccine in cattle. Res. Opin. Anim. Vet. Sci., 4(4) (2014): 178-185.

[12] Elwatany, H., Shawky, M.M., Roshdy, O.M. and El-Kelany, S.: Relationship between cellular and humoral immunity responses in animal vaccinated with FMD vaccine. Zagazig Vet. J., 27(1)(1999): 49-57.

[13] Fakhry, H.M., Rizk, S.A., Abu-Elnaga, H.I., Deghaidy, W., Talaat, A.A. and Hegazi, A.Z.: Field application of bivalent foot and mouth disease vaccine adjuvanted with Montanide ISA $(25,50,206)$ and IMS (1113$3015)$ as an alternative to aluminum hydroxide gel. Egypt. J. Virol., (2012) 9(1): 123-136

[14] Farag, M.A., Aggour, M. A. and Daoud, A.M.: ELISA as a rapid method for detecting the correlation between the field isolates of FMD and the current used vaccine strain in Egypt.Vet. Med. J. Giza, Vol. 53 no. 4 (2005): 949- 955.

[15] Gupta,R.K., Rost,B.E., Relyveld,E. and Siber,G.R.: Adjuvant properties of aluminum and calcium compounds, Pharm. Biotechnol. 6 (1995) 229-248.

[16] Hamblin,C., Barnett,I.T.R. and Crowther,J.R.: New Enzyme-Linked Immuno Sorbent Assay (ELISA) for the detection of antibodies against FMD virus. П Application.Journal of immunological methods, 93(1986): 123-129.

[17] Henderson, W.M.: A comparison of different routes of inoculation of cattle for detection of the virus of foot and mouth disease.J.Hyg.Camb., 50 (1970) : 182-194.

[18] Hiam, M., Fakhry, Sonia, A., Rizk, Hany, I., Abu-Elnaga, Wafaa Deghaidy, Abeer,A., Talaat and Hegazi, A. Z.: Field application of bivalent foot and mouth disease vaccine adjuvanted with montanide ISA $(25,50,206$, 1113) and IMS 3015 as an alternative to aluminum hydroxide gel. Zag. Vet. J. (ISSN. 1110-1458) vol. 40 No. 5(2012)

ARC Journal of Animal and Veterinary Sciences
[19]Iyer,S., HogenEsch H. and Hem, S. L.: Relationship between the degree of antigen adsorption to aluminum hydroxide adjuvant in interstitial fluid and antibody production.(2003), Vaccine, 21.

[20] Iyer, A., Ghosh, S., Singh, S., Deshmukh. R.: Evaluation of three 'ready to formulate' oil Adjuvants for foot-and-mouth disease vaccine production. Vaccine. (2000);19:1097-1105.

[21] Knudsen, R.C., Groocock, C.M. and Aaderson, A.A.: Immunity to foot-and-mouth disease virus in guinea pigs: clinical and immune responses. Infection and Immunity 24(1979): 787-792.

[22] Lombard, M., Pastoret,P.P. and Moulin, A.M.: A brief history of vaccines and vaccination.Rev. Sci.Tech. (2007) 26 (1):2948 .

[23] Longjam, N., Deb, R., Sarmah, A.K., Tayo, T., Awachat, V.B. and Saxena, V.K.: A brief review on diagnosis of foot and- mouth disease of livestock: Conventional to molecular tools. Vet. Med. Int., (2011): 905768.

[24] Mercedes G. V.,Timothy D., Trevor C., Martin R. and R. Michael E. P.: Recognition of foot-and-mouth disease virus and its capsid protein VP1 by bovine peripheral $\mathrm{T}$ lymphocytes. Journal of General Virology (1996), 77, 727-735.

[25] Nader M. Sobhy, Sunil K. Mor, Mohammed E.M. Mohammed, Iman M. Bastawecy, Hiam M. Fakhry, and Sagar M. Goyal,: Phylogenetic analysis of Egyptian foot and mouth disease virus endemic strains in 2013. $5^{\text {th }}$ international conference of virology (December 9-12/2014), Egyptian J. virol.,Vol. 11 (1) 49-59,(2014).

[26] OIE: OIE manual of standards: Anon. Section 2.1. List - Diseases, Chapter 2.1.1. Foot-and mouth disease. OIE manual of standards for diagnostic tests and vaccines; 4th Ed. (2000), Paris, 77-92.

[27] OIE: Manual of diagnostic tests and vaccines for terrestrial animals. OIE, Paris, France: (2012). Foot and mouth disease. Chapter 2.1.5.

[28] Orsel,K.;deJong,M.C.;Bouma, A.; Stegeman ,J.A. and Dekker,A.: Foot and mouth disease virus transmission among vaccinated pigs after exposure to virus shedding pigs. Vaccine 2 21;25(34) (2007): 6381-91.

[29] Park,J.H.: Requirements for improved vaccines against foot-and-mouth disease epidemics, Clin. Exp. Vaccine Res. 2 (2013) 818.

[30] Park,M.E., Lee,S.Y., Kim,R.H., Ko, M.K., Lee,K.N., Kim,S.M. et al.: Enhanced immune responses of foot-and-mouth disease vaccine using new oil/gel adjuvant mixtures in pigs and goats, Vaccine (2014). 
[31] Patil,P.K., Bayry,J., Ramakrishna,C., Hugar, B., L.D. Misra,L.D. and Natarajan,C.: Immune responses of goats against foot-and-mouth disease quadrivalent vaccine: comparison of double oil emulsion and aluminium hydroxide gel vaccines in eliciting immunity, Vaccine 20 (2002a) 2781-2789.

[32] Patil,P.K., Bayry,J., Ramakrishna,C., Hugar,B., Misra,L.D., Prabhudas,K., et al.: Immune responses of sheep to quadrivalent double emulsion foot-and-mouth disease vaccines: rate of development of immunity and variations among other ruminants, J. Clin. Microbiol. 40 (2002b) 4367-4371.

[33] Reddy,G.S. and Srinivasan,V.A.: Performance of aluminium hydroxide gel and oil adjuvant rabies vaccines in bovines, Zentralbl Bakteriol 286 (1997) 523-526.

[34] Rimaniol,A.C.,Gras,G. et al.: Aluminum hydroxide adjuvant induces macrophage differentiation towards a specialized antigenpresenting cell type, Vaccine 13 (22) (2004) 3127-3135.

[35] Rodriguez, L.L. and Grubman, M.J.: Foot and mouth disease virus vaccines. Vaccine, 27 Suppl 4(2009): D90-4.

[36] Satya, P.: Vaccination against foot-and-mouth disease virus: Strategies and effectiveness. Expert Rev. Vaccines, 8(3) (2009): 347-365.

[37] Sharma, M.C., Pathak, M.N. Hung, M.N., Nhi D.L. and Vuc, N.V.: Report on the out break of foot and mouth disease in buffaloes in the southern part of Vietnam. Veterinary viral diseases (1984): 302-305.
[38] Sonia,A., Rizk, Hiam, M., Fakhry and AbuElnaga, H.I.: Comparative study of $\mathrm{T}$ cell proliferative response in cattle vaccinated with FMD vaccine using Cell titre Aqueous one solution non radioactive assay (MTS). Zag. Vet. J. (ISSN. 1110-1458) Vol. 38, No. 4 pp. 188-195 (2010).

[39] Scudiero, D.A., Shoemaker, R.H., Paull, K.D., Monks, A., Tierney, S., Nofziger, T.H., Currens, M.J., Seniff, D. and Boyd, M.R.: Evaluation of soluble tetrazolium/Formazan Assay for cell growth and drug sensitivity in culture using human and other tumer cell lines. Cancer Research Journal, 48 (1988): 48274833.

[40] Shawky M., Abd El-Aty M., Hiam. M. Fakry, Hind M. Daoud, Ehab El-Sayed I., Wael Mossad G., Sonia A. Rizk, Abu-Elnaga H., Mohamed A. A., Abd El-kreem A. and Farouk E. M.: Isolation and Molecular Characterization of Foot and Mouth Disease SAT2 Virus during Outbreak 2012 in Egypt. $J$ Vet Adv (2013), 3(2): 60-68.

[41] Voller, A., Bid Well, D. and Bartleha: Micro plate enzyme immuno assay for the immuno diagnosis of virus infection. Am. Soc. For Micro. (506-512) (1976).

[42] Wisniewski J., Kobusiewiecz T., Baronowski C.,and Jankowsko J.,: Determination of the level of immunity in cattle on the basis of neutralizing antibodies after the use of Frenkel type FMD vaccine. Medycyna Wet 28 (10) (1972):586-588

[43] Zahran, G.E.D.: Foot and mouth disease in southern region of URA.Bull. Off. Int. Epiz., 13 (1960): 390- 393.

Citation: Wael M. Gamaledin, Ehab Elsayed, Amr I. Hassanin, Assem A. Mohamed, Walaa Shabana. Performance of Aluminium Hydroxide Gel and ISA Oils Adjuvanted Foot and Mouth Disease Vaccines. ARC Journal of Animal and Veterinary Sciences. 2019; 5(3):1-9. doi: dx.doi.org/10.20431/2455-2518.0503001.

Copyright: (C) 2019 Authors. This is an open-access article distributed under the terms of the Creative Commons Attribution License, which permits unrestricted use, distribution, and reproduction in any medium, provided the original author and source are credited. 